\title{
A GERAÇÃO DE RESÍDUOS SÓLIDOS POR CURTUMES E ALTERNATIVAS DE TRATAMENTO E REÚSO
}

\section{SOLID WASTES GENERATED BY TANNERY AND ALTERNATIVES FOR TREATMENT AND REUSE}

Gabriella Elisa Silva Nogueira

Mestranda do Programa de Pós-Graduação em Tecnologias e Inovações Ambientais da Universidade Federal de Lavras. (gabriellanogueirasgp@gmail.com)

Karina Heck da Silva

Doutora em Agronomia (Microbiologia Agricola)/ESALQ-USP. (kheck bio@hotmail.com)

Adelir Aparecida Saczk

Doutora em Química/UNESP. Programa de Pós-Graduação em Agroquímica da Universidade Federal de Lavras. (adelir@dqi.ufla.br)

André Geraldo Cornelio Ribeiro

Doutor em Engenharia Civil (Geotecnia)/UFV. Departamento de Engenharia da Universidade Federal de Lavras. (andreribeiro@deg.ufla.br)

\section{Resumo}

As atividades industriais geram resíduos de formas variadas que, predominantemente, apresentam um elevado grau de poluição, tendo, na maioria das vezes, os aterros industriais como disposição final. A indústria do couro é uma grande geradora de resíduos industriais, os quais apresentam volume residual da pele e de cromo, do couro curtido e do tratamento dos efluentes gerados durante a produção. Aterrar resíduos de curtume, além de um potencial risco de contaminação ambiental, gera gastos e resulta em desperdício de material potencialmente reaproveitável. Diante da necessidade de alerta e alternativas ao aterramento desses resíduos, tratamentos para a remoção do cromo, através de processos físico-químicos e biológicos, são indicados para o reaproveitamento do material. 0 objetivo deste trabalho foi revisar a literatura científica em busca das informações consagradas sobre as diferentes metodologias aplicadas na recuperação do resíduo. Há uma inclinação pela adoção de técnicas que removem o cromo de efluentes e do lodo de curtume para seu melhor reaproveitamento e incorporação em diversos setores produtivos.

Palavras-chave: Resíduo de Curtume. Lodo de ETE. Cromo

\begin{abstract}
Industrial activities produce several kind of waste that may present high pollution degree and are mostly forwarded to industrial landfill. Leather industry is a potent waste producer, presenting a high amount of cattle skin waste generated from tannery and effluent treatment process. Landfill of waste tannery demands industrial costs and promotes the loss of potentially useful materials, in addition to therisks of environmental contaminations. There isan urgency for alternatives screening for organic and chromium wastes removal out of effluent and sludge produced along the tannery process, in order to avoid the waste disposal on landfill. Chemical, physical and biological techniques are known and useful to remove the chromium and organic waste out, in order to reuse the tannery wastes. The aim of this study was to screen solid and recent informations about the methods applied in tannery waste treatment. It is observed a tendency for suitable methods to remove the chromium out of effluent and sludge toward to a best tannery waste useful.
\end{abstract}

Keywords: Tannery waste. Sludge. Chromium 


\section{INTRODUÇÃO}

O crescimento da população mundial vem exigindo um consumo de recursos naturais e produtos manufaturados em ordem crescente. Esses fatores implicam em um aumento na quantidade de resíduos sólidos gerada. Atualmente, uma porcentagem irrisória dos resíduos gerados é reciclada. Se considerarmos especificamente os resíduos industriais, uma parcela menor ainda é reciclada ou reaproveitada, sendo a sua grande parte destinada a aterros sanitários ou abandonada em locais inadequados (RUIZ et al., 2015). Com o surgimento das discussões sobre a importância do desenvolvimento sustentável e, consequentemente, da gestão ambiental, as autoridades de fiscalização passaram a pressionar o setor industrial e consumidores através de legislações que protegem os ecossistemas dos poluentes que compõem os resíduos (ALVES; BARBOSA, 2013; SANTOS et al., 2015).

Variações no fluxo e nas características dos resíduos produzidos podem ocorrer em indústrias do mesmo segmento mercantil. Isso acontece devido a diferentes formas de gestão de produção e gestão ambiental (YANG, 1996), indicando que adequados procedimentos possam diminuir a quantidade de resíduos gerados, minimizando os impactos ambientais causados. Qualquer atividade industrial gera resíduos em maior ou em menor quantidade e escala de poluição, e as crescentes demandas ambientais obrigam os processos produtivos industriais a reutilizar certa parcela de seus resíduos. Além de importante para a preservação do ambiente, a reutilização de resíduos sólidos é também de grande interesse econômico, pois, quanto menor for a quantidade de resíduo ineficiente gerado, menos oneroso será o orçamento em gerenciamento desses resíduos para as indústrias, podendo tornar-se uma solução sustentável para a produção de matéria-prima, energia, combustíveis e produtos químicos (BAUTISTA et al., 2015).

O processo de curtimento consiste em transformar peles cruas de gado em couro, um material não putrescível que pode ou não receber uma variedade de tratamentos adicionais e aplicações finais. Dentre os principais problemas associados à atividade de curtume, o grande volume de resíduos líquidos e sólidos gerados requer atenção especial, já que a forma mais frequente de gestão desses resíduos é o aterramento (FERNÁNDEZSEMPERE et al., 1997; SANTOS et al., 2015). O nível de dificuldade de caracterização desses tipos de resíduos deve-se à grande variedade de produtos e processos utilizados na indústria do couro, de acordo com o fluxograma empregado. Lodos de curtumes apresentam uma alta quantidade de matéria orgânica oriunda da pele tratada, concentrações significativas de micro-organismos potencialmente patogênicos, alto teor de cromo, além de outras substâncias inorgânicas, como enxofre, nitrogênio e fósforo, que são macronutrientes.

A investigação da concentração de cromo no efluente é imprescindível, por ser o agente de curtimento mais utilizado, compreendendose que os estados redox cromo III (trivalente) e o cromo VI (hexavalente) estão presentes nos resíduos. O cromo $\mathrm{VI}$ é mais tóxico que o cromo III, devido à sua alta taxa de absorção através do epitélio do trato intestinal, especialmente ao homem. Entretanto, o cromo VI pode ser reduzido (processo atômico que envolve ganho de elétrons) a cromo III (estado menos oxidado) no ambiente, o que pode atenuar suas implicações tóxicas (MAKDISI, 1991). O couro é submetido a diversos processos, estando o cromo presente na maioria dos resíduos gerados por curtumes, o que os torna perigosos e/ou tóxicos (FERNÁNDEZ-SEMPERE et al., 1997; ZHOU et al., 2006).

A necessidade de busca por alternativas de tratamentos de natureza física, química ou biológica para a remoção de cromo do efluente de curtume, bem como de metodologias que possibilitem o reaproveitamento do lodo do efluente nos diversos âmbitos da reciclagem de materiais, é imprescindível na promoção de melhorias no gerenciamento de resíduos dessas indústrias. Assim, o objetivo do presente trabalho foi revisar, na literatura, as técnicas comumente utilizadas para a remoção de cromo do efluente contaminado, bem como as possibilidades de reciclagem do lodo produzido após a referida atividade industrial. 


\section{MATERIAL E MÉTODOS}

A pesquisa foi realizada entre fevereiro de 2016 e abril de 2017 por meio de busca, no portal de periódicos da Coordenação de Aperfeiçoamento de Pessoal de Nível Superior (CAPES) (www.periodicos.capes.gov.br), por publicações científicas e do estado da arte referentes ao assunto, bem como de consulta a resultados de pesquisas e análises divulgadas, como temas de reuniões científicas, dissertações e teses acadêmicas. Foi realizada, portanto, uma varredura em busca de técnicas e metodologias de remoção de cromo dos resíduos da atividade de curtume, em sistemas aquosos e em solos, bem como de reaproveitamento do lodo de curtume.

\section{RESULTADOS E DISCUSSÃO}

Aterrar resíduos de curtume, além de um potencial risco de contaminação ambiental, há bastante tempo, resulta em uma considerável perda de energia e produtos. Estudos realizados na década de 80 apontaram que a perda de energia estimada nesse processo é de $633 \mathrm{TJ}$ (equivalente a $1,513 \times 10^{11} \mathrm{Kcal}$ ) por ano, e que a perda de cromo é de aproximadamente 8200 toneladas, isso com taxa de produção de 11 milhões de unidades de peles, por ano, nos Estados Unidos (MURALIDHARA et al., 1982). Atualmente, o curtimento de uma tonelada de peles produz aproximadamente $250 \mathrm{Kg}$ de couros acabados e uma média de $650 \mathrm{Kg}$ de resíduos sólidos, podendo chegar até $1.000 \mathrm{Kg}$ de resíduos sólidos gerados pela atividade. Esses números, atrelados ao alto potencial poluidor de um curtume, podem até mesmo inviabilizar as operações industriais (SANTOS et al., 2015). Em escala mundial, a indústria do couro gera cerca de quatro milhões de toneladas de resíduos sólidos por ano (FELA et al., 2011). No Brasil, a indústria de curtumes é um importante segmento econômico que tem crescido nos últimos anos, atingindo a produção de 44 milhões de peças de couro em 2006, representando, na época, 20\% do mercado mundial. Em 2007, houve uma expansão de mercado, considerando que 34,6 milhões de peças de couros foram exportados, compreendendo $78 \%$ da produção de couro no país para aquele ano. Em 2011, o Brasil ganhou destaque no mercado mundial pela produção de carnes de corte bovinas, ocupando o segundo lugar de país produtor de carnes mundial, ou seja, atrás apenas dos Estados Unidos (DEPEC - BRADESCO, 2013). Como consequência, nesse mesmo ano, o Brasil se tornou o quinto maior produtor de couros, ficando atrás dos Estados Unidos, Rússia, Índia e Argentina (SANTOS, 2015).

\section{Cromo}

O cromo é apresentado, na tabela periódica, como um metal de transição de número atômico 23 e massa atômica de 51,996 . Os usos mais comuns do cromo são nas indústrias de cromagem, mineração e curtumes, sendo, assim, encontrados em concentrações elevadas e livres no ambiente onde estão instaladas estas indústrias e atividades (FREITAS; MELNIKOV, 2006). Portanto, esse elemento é uma das mais importantes fontes de contaminação ambiental, devido às grandes quantidades de águas residuais produzidas e pela geração de lodo proveniente do tratamento dessas águas (KILIÇ; FONT et al., 2011; KILIÇ; PUIG et al., 2011).

Uma variação de $80-90 \%$ dos curtumes mundiais utilizam sais de cromo III em seus processos de curtimento (KILIÇ; FONT et al., 2011; CELARY; SOBIK-SZOLTYSEK, 2014; MONTAÑÉS et al., 2014). Couros curtidos ao cromo oferecem uma boa resistência mecânica e melhor resistência hidrostática, em comparação a outros couros curtidos com conservantes vegetais, como o tanino de acácia (único produzido no Brasil), de castanheiro e de quebracho (NASHY et al., 2012; MONTAÑÉS et al., 2014). Os sais de cromo também possuem uma alta taxa de penetração nos espaços interfibrilares da pele, o que gera economia de tempo no processo de curtimento, bem como um melhor controle desse pocesso, além de maior homogeneidade e ocupação da superfície do tecido em tratamento (MONTAÑÉS et al., 2014). Agentes curtentes à base de taninos vegetais são bastante utilizados em curtumes brasileiros, principalmente na etapa de recurtimento do couro, existindo como parte complementar do processo de curtimento do couro ao cromo. 
Entretanto, com a demanda ambiental imposta pelas legislações, espera-se que os taninos vegetais sejam empregados em maior escala, principalmente em substituição ao cromo, por produzirem produtos de qualidade e gerarem resíduos biodegradáveis e não prejudiciais à saúde pública e ao ambiente (CETESB, 2015).

A descoberta do cromo como agente curtente é atribuída a Knapp, em 1858, na Alemanha, mas somente três décadas depois, em Nova York, houve a produção de couro curtido ao cromo em escala comercial (ABREU; TOFFOLI, 2009). Mais de $90 \%$ da produção mundial de couro ocorre através do curtimento com sais de cromo, considerando que cada peça de pele gera, em média, $7,5 \mathrm{Kg}$ de resíduo com cromo, podendo gerar 330 mil toneladas por ano, somente no Brasil. Isso implica que os processos de curtimento ao cromo causam significativas perdas de materiais, bem como grandes impactos ao meio ambiente (ABREU; TOFFOLI, 2009).

Quando o cromo é utilizado no processo de curtimento tradicional, um percentual entre 54 e $57 \%$ do cromo utilizado reage nas peles, e o restante é descartado através de resíduos líquidos e sólidos (KILIÇ; FONT et al., 2011; ZOU et al., 2013). Ambas as formas do cromo podem ser solubilizadas e lixiviadas através do solo, comprometendo as características originais do local, níveis freáticos e corpos d'água, bem como a saúde ambiental de diferentes ambientes e seres vivos. Da mesma forma que o cromo $\mathrm{VI}$ pode ser reduzido a cromo III, em certas substâncias, este pode ser oxidado a cromo VI (KILIÇ; FONT et al., 2011).

O cromo VI pode ser encontrado por adsorção aniônica, enquanto o cromo III pode ser encontrado no solo ou na água, em reações de adsorção, hidrólise e quelação, e como resultado da redução química de cromo hexavalente (VI) para cromo trivalente (III). No solo, a mobilidade do cromo é complexa. O cromo III é termodinamicamente estável em ambientes oxidados. Geralmente, níveis altos de cromo VI indicam poluição industrial. Tanto o cromo III como o cromo VI são cineticamente inertes e podem ter uma estabilidade aparente para reações redox em condições termodinamicamente estáveis. Porém, na presença de matéria orgânica em soluções ácidas, o cromo VI é prontamente reduzido a cromo III (MAKDISI, 1991).

$\mathrm{Em}$ pequenas quantidades, muitos elementos químicos, como o cromo, são chamados micronutrientes, pois são essenciais para o crescimento de plantas, aos microorganismos e para o bom funcionamento do organismo dos seres humanos e outros animais. Porém, em concentrações elevadas, podem interferir nas atividades bioquímicas dos micro-organismos presentes no ambiente, promovendo, entre estes, a resistência a metais pesados em solos contaminados, prejudicar o crescimento de plantas, inibindo a germinação de sementes e crescimento de plântulas, e se tornar cumulativo em seres humanos (BRUINS et al., 2000; FREITAS; MELNIKOV, 2006; HAROUN et al., 2007; KILIÇ; FONT et al., 2011; HECK et al., 2015). Sua toxicidade depende principalmente de sua forma química. Compostos de cromo III são menos tóxicos do que de cromo $\mathrm{VI}$; este último é conhecido por ser muito móvel e volátil, perigoso para a saúde humana através de inalação, contato com a pele e ingestão, sendo carcinogênico e mutagênico em organismos vivos, alterando a permeabilidade de membrana e canais iônicos, mesmo em concentrações muito baixas (CHUAN; LIU, 1996; FREITAS; MELNIKOV, 2006; ABREU; TOFFOLI, 2009; JAISHANKAR et al., 2014).

\section{Processo de curtimento}

O processamento do couro é uma atividade que surgiu quando 0 homem começou a caçar animais para alimentação, desenvolvendo uma indústria de um subproduto. O couro é um tecido natural do gado, formado por fibras de colágeno em uma estrutura tridimensional. O colágeno é convertido em couro, quando em contato com os agentes curtentes nas condições adequadas. Isso significa que o processo de curtimento é um dos mais importantes no curtume, em que a proteína da pele se torna material estável e resistente à degradação enzimática (NASHY et al., 2012). Assim, a fabricação do couro se faz essencial pelas propriedades únicas de seu produto, em termos de resistência, conforto, durabilidade e outras propriedades significativas. 
O curtimento é o processo chave que torna a pele natural em material estabilizado e resistente ao calor, umidade, degradação enzimática e estresse mecânico (ABREU; TOFFOLI, 2009). Entretanto, apenas parte do volume em solução dos sais de cromo utilizado no processo de curtimento produz a reação desejável com as peles. Isso ocorre devido ao acesso limitado aos sítios reativos para as moléculas responsáveis pela reação química de curtimento, ou seja, a penetração homogênea da solução em toda a área do tecido. O restante dos sais é liberado nos efluentes do processo industrial que, quando tratados, geram o lodo da estação de tratamento de efluentes, que são ricos em cromo (CELARY; SOBIK-SZOŁTYSEK, 2014), bem como em matéria orgânica, como resíduos celulares, ambos provenientes do processo industrial.

O processamento do couro consiste, portanto, em transformar a pele em couro para comercialização. Trata-se de uma complexa combinação entre processos físicos e químicos. Sua tecnologia de fabricação requer diversas etapas de processamento da transformação, que podem ser agrupadas em: ribeira, curtimento, pré-acabamento e acabamento. A ribeira consiste na preparação e separação dos lotes de couro, por peso, passando por diversos banhos, sendo eles o banho de remolho, banho de depilação/caleiro (considerado altamente poluidor por utilizar, em sua composição, cal e sulfeto de sódio), descarne, divisão, pesagem, banho de desencalagem, banho de purga e banho de píquel. Os banhos são realizados em fulões (grandes tambores de madeira ou qualquer outro material resistente, os quais giram em torno de seu próprio eixo). Nesta primeira etapa, ocorre a geração de resíduos sólidos, líquidos e gasosos.

$\mathrm{Na}$ segunda etapa, no curtimento, são gerados efluentes líquidos. Posteriormente, o couro entra em processo de pré-acabamento, que consiste, inicialmente, no enxugamento e rebaixamento do tecido. Após essa etapa, em meio aquoso, o material passa pelos banhos de neutralização, lavagem, recurtimento, tingimento e engraxe, gerando resíduos sólidos, líquidos e gasosos, novamente. Finalmente, o couro é levado à secagem e passa por condicionamento, amaciamento, estaqueamento, recorte, lixamento, desempoamento, impregnação, prensagem e medição. São etapas do acabamento que variam de acordo com o artigo fabricado. Nessa última etapa, também são gerados resíduos sólidos, líquidos e gasosos (MAKDISI, 1991; YANG, 1996; AMIR et al., 2008; FELA et al., 2011; ALVES; BARBOSA, 2013). O fluxograma do processo de curtimento é apresentado na Figura 1.

\section{A problemática dos resíduos}

Resíduos de processos industriais podem ser classificados em três tipos, conforme os estados da matéria: resíduos sólidos, resíduos líquidos e resíduos gasosos. Estes últimos, por sua vez, podem ser classificados segundo a sua origem, ou seja, se são provenientes das matérias-primas utilizadas, ou se oriundas das reações que ocorrem ao longo do processo (YANG, 1996). Assim, muitas características dos resíduos podem ser estimadas a partir de uma compreensão adequada do processo produtivo.

A maioria dos resíduos de couro curtido é inutilizável. O processo produtivo dos curtumes gera grande quantidade de águas residuais, pois a maioria dos processos de curtimento ocorre em meio aquoso. O efluente gerado é contaminado por diversos produtos químicos utilizados e pelas proteínas provenientes das peles, e demanda tratamento. Entretanto, como resultado desse tratamento, são gerados resíduos sólidos, chamados de lodos de estação de tratamento de efluentes (ETE) de curtumes. Tais resíduos precisam ser encaminhados para aterros industriais adequados, devido à sua ação poluente (FELA et al., 2011). Todavia, quando os aterros industriais se localizam em áreas muito distantes da produção desses resíduos, os "lixões" ainda ativos são uma alternativa menos onerosa para essas indústrias, mesmo que este ato seja proibido pela legislação brasileira (BRASIL, 2010; NEPOMUCENO et al., 2016).

O resíduo de curtume contendo cromo deve ser tratado como resíduo perigoso, apesar de ser essencialmente orgânico. Cabe ressaltar que o tratamento e/ou destinação correta deste resíduo não ocorre, na maioria das vezes, devido ao seu alto ônus 
orçamentário para a empresa. Como resultado, por vezes, esse resíduo é descartado sem segurança, impondo riscos ao ambiente $e$ desperdiçando materiais que, porventura, possam ser reaproveitados, como no caso da recuperação do cromo, do aproveitamento da porção orgânica dos resíduos (como pelos, gordura, lodos de tratamento biológico), das cinzas (resultantes do aquecimento do combustível utilizado, no caso, lenha) e fuligens das caldeiras (resultantes da combustão incompleta da lenha) (NASHY et al., 2012; VIANA; CRUZ, 2016). Sabendo-se que a indústria do couro é fonte significativa de resíduos sólidos perigosos, alguns de seus resíduos, como as aparas caleadas provenientes do processo anterior ao curtimento, podem ser facilmente reaproveitados em indústrias que utilizam o colágeno como matéria-prima. A classificação desses resíduos, bem como sua reutilização, reciclagem e eliminação dependem tanto do contexto legal, como do mercado disponível para a reciclagem (RIVELA et al., 2004).

Figura 1. Fluxograma do processo de curtimento de couro em indústria de curtume. Entradas de matériaprima e saídas de resíduos são mostradas nas etapas da produção.

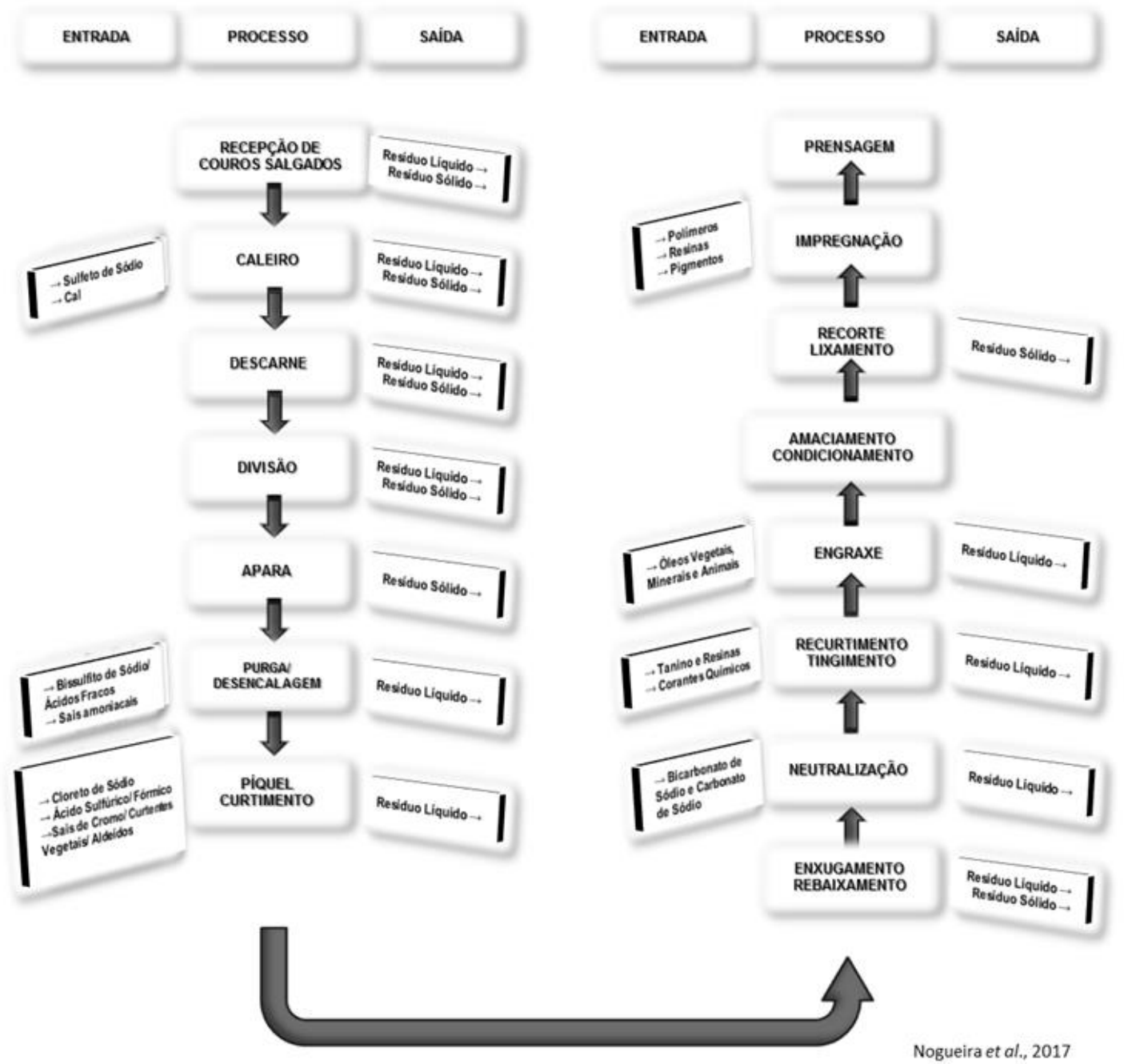

Fonte: Dos autores.

A preocupação acerca da contaminação ambiental por metais pesados se estende em âmbito mundial. Para minimizar os impactos e transtornos ocasionados pela contaminação de solos por altas concentrações desses elementos, órgãos de fiscalização brasileiros, como o Conselho Nacional do Meio Ambiente (CONAMA), preconizam limites máximos que 
podem ser depositados por via de incorporação de materiais contaminados, tratados e estabilizados, através da Resolução 375/2006 (BRASIL, 2006). Ainda no Brasil, resíduos sólidos de curtume são classificados como perigosos, segundo a Lei Federal 12.305, de 02 de agosto de 2010, que dispõe sobre a Política Nacional de Resíduos Sólidos (BRASIL, 2010). Nos Estados Unidos, a Agência de Proteção Ambiental dos Estados Unidos (USEPA) considera resíduos que contenham cromo como sendo constituintes perigosos (MONTAÑÉS et al., 2014). Na Índia, resíduos sólidos de curtumes são categorizados como "vermelhos", o que significa que as atividades da indústria podem causar um alto dano ambiental; nesse caso, é inviabilizada a liberação de licença de operação (FATHIMA et al., 2012).

Já em Marrakech, no Marrocos, indústrias de curtumes são consideradas um grande perigo para o ambiente, pois todos os seus resíduos são descarregados no ambiente sem nenhum tratamento prévio, já que não há órgãos públicos que fiscalizem o gerenciamento de resíduos por parte das empresas poluentes (AMIR et al., 2008). Em países como a Alemanha, a aprovação de locais de construção de novos aterros é praticamente inviável, devido à problemática de espaços geográficos disponíveis, sendo a liberação de aterros licenciados algo raro. Assim, tecnologias que diminuam o volume de lodo gerado, bem como que atendam aos regulamentos ambientais, são idealizadas há bastante tempo (SKRYPSKI-MÄNTELE; BRIDLE, 1995). Em Taiwan, desde novembro de 1985, a legislação local prevê que lodos de processos de curtumes, bem como os resíduos sólidos gerados na fabricação do couro, sejam classificados como perigosos, o que demonstra, por fim, que resíduos contaminados com cromo são considerados arriscados desde o século passado (CHUAN; LIU, 1996).

Como exemplo de seu potencial poluidor, pode-se citar o caso de um curtume na Califórnia (EUA) que teve suas atividades encerradas e a área vendida, a fim de dar início a uma ocupação comercial e residencial. Com esse propósito, fez-se necessária uma análise do solo da área, objetivando investigar a presença de contaminantes. Os resultados apontaram que os principais contaminantes encontrados foram o cromo e óleos sulfonados, ambos utilizados no processo de curtimento do couro. Os óleos sulfonados foram achados em quantidades consideradas não perigosas na Califórnia, porém, o cromo foi encontrado em quantidades de 1.000 a $40.000 \mathrm{mg} \cdot \mathrm{Kg}^{-1}$, sendo que a legislação vigente na Califórnia permite apenas $2,5 \mathrm{mg} \cdot \mathrm{Kg}^{-1}$. Por esse motivo, a área foi submetida a tratamento ex situ, que consistiu na retirada de parte do solo através de escavação para outra área para processo de remediação. O cromo remanescente no solo remediado não precisou ser retirado devido ao baixo risco para a saúde pública e para possíveis danos ambientais posteriores (MAKDISI, 1991). Esse estudo evidencia os riscos de contaminação ambiental por parte das atividades de curtumes em longo prazo, o que aponta, em muitas ocasiões, em direção a uma emergência de remediação para a remoção de cromo.

Na cidade de Presidente Prudente, (São Paulo, Brasil), uma indústria de curtume produz, a cada 3 mil peças de couro, um volume de $19 \mathrm{~m}^{3}$ de resíduos em lodo, e o custo de enviar esse montante para o aterro chega em torno de $\mathrm{R} \$ 1.500,00$ (RUIZ et al., 2015). Uma possível alternativa a toda essa quantidade de resíduos contendo cromo pode ser a utilização apenas de curtentes vegetais (taninos), que contribuem através de composição química polifenólica para o processo de industrialização das peles. O curtimento vegetal tende a ser mais demorado que os outros tipos de curtimentos, mas, como alternativa, utilizam-se produtos químicos auxiliares na etapa de pré-curtimento, a fim de se obter um produto de qualidade e menos nocivo ao ambiente (LOPES, 2016).

\section{Alternativas de remoção de cromo, tratamento, reaproveitamento e disposição final de resíduos de curtume}

Os lodos e demais resíduos de curtumes, mesmo quando aterrados adequadamente, geram a perda de cromo como matéria-prima. A recuperação do cromo a partir do lodo de curtume pode minimizar os riscos potenciais à saúde e ao ambiente, dada a aplicação deste lodo em solos para aproveitamento do resíduo como fertilizante, possibilitando utilizar, ainda, 
parte do valor econômico que se gastaria com cromo como matéria-prima industrial (KILIÇ; FONT et al., 2011). Para ampliar a aplicabilidade e reuso do efluente ou do lodo, de forma a reduzir os riscos de contaminação no ambiente, tratamentos físicos, químicos e biológicos de remoção do cromo são descritos pela literatura e proporcionam uma gama de alternativas de disposição. Eles são empregados de acordo com a concentração de cromo e outros poluentes inorgânicos presentes em solução, com a presença de matéria orgânica $e$, principalmente, com a disponibilidade de recursos de energia $e$ tecnologia (Quadro 1).

\section{Quadro 1: Principais métodos físicos e químicos de remoção do cromo III e VI de efluente} contaminado

\begin{tabular}{|c|c|c|}
\hline Técnica & Fundamento & Referência \\
\hline Precipitação & $\begin{array}{l}\text { Emprego de agentes precipitantes em } \\
\text { solução }\end{array}$ & Mirbagheri; Hosseini, 2005 \\
\hline Eletrocoagulação & $\begin{array}{l}\text { Emprego de agentes coagulantes } \\
\text { produzidos em eletrodos. Processo } \\
\text { mediado por efeito de flotação do } \mathrm{H}_{2}\end{array}$ & Chen, 2004 \\
\hline $\begin{array}{l}\text { Nanotubos de } \\
\text { carbono }\end{array}$ & $\begin{array}{l}\text { Emprego de microtubos de carbono } \\
\text { grafite. Atração eletrostática entre o } \\
\text { material e íons metálicos }\end{array}$ & Rao et al., 2007 \\
\hline Eletrodiálise & $\begin{array}{l}\text { Emprego de membrana de troca iônica } \\
\text { em campo elétrico }\end{array}$ & Lambert et al., 2006 \\
\hline Flotação de íons & $\begin{array}{l}\text { Emprego de surfactantes com afinidade } \\
\text { com íons metálicos. Mediação por } \\
\text { agentes de flotação }\end{array}$ & Polat; Erdogan, 2007 \\
\hline Ultrafiltração & $\begin{array}{l}\text { Complexação de íons metálicos com } \\
\text { polímeros solúveis e filtração por } \\
\text { membrana de alta eficiência }\end{array}$ & Barakat; Schmidt, 2010 \\
\hline Nanofiltração & $\begin{array}{l}\text { Filtração por membrana semipermeável } \\
\text { de nanoporos }\end{array}$ & Erikson, 1988 \\
\hline $\begin{array}{l}\text { Agentes } \\
\text { quelantes }\end{array}$ & $\begin{array}{l}\text { Formação de complexos altamente } \\
\text { estáveis com os íons metálicos, utilizando } \\
\text { EDTA, ácido acético ou ácido clorídrico }\end{array}$ & Gitipour et al., 2016 \\
\hline $\begin{array}{l}\text { Agentes } \\
\text { oxidantes }\end{array}$ & $\begin{array}{l}\text { Uso de forte poder de oxidação de } \\
\text { compostos metálicos }\end{array}$ & Souza e Silva et al., 2006 \\
\hline
\end{tabular}

Fonte: Dos autores.

Precipitação - ocorre por aplicação de hidróxido de cálcio $\left[\mathrm{Ca}(\mathrm{OH})_{2}\right]$ e hidróxido de sódio $(\mathrm{NaOH})$ no efluente para a remoção do cromo VI. Nesse processo, o cromo VI é reduzido primeiramente a cromo III por uso de sulfato ferroso $\left(\mathrm{FeSO}_{4}\right)$, para, então, perfazer a precipitação do cromo III por emprego de $\mathrm{Ca}(\mathrm{OH})_{2}$. A concentração inicial de cromato, de $30 \mathrm{mg} \cdot \mathrm{L}^{-1}$ de efluente em tratamento, pode ser reduzida a $0,01 \quad \mathrm{mg} \cdot \mathrm{L}^{-1} \quad$ (MIRBAGHERI; HOSSEINI, 2005). Essa metodologia de remoção pode ser otimizada por adição de coagulantes ao sistema. A contrapartida é a ocorrência de solubilização de outros metais no efluente, de acordo com diferentes faixas de $\mathrm{pH}$ empregadas, além de possível inibição da precipitação por agentes complexantes presentes no efluente (FU; WANG, 2011). 
Eletrocoagulação - entre os tratamentos químicos pertinentes à separação e resgate de cromo de efluente, a eletrocoagulação é alternativa como técnica. Esta promove a geração de coagulantes in situ, dissolvendo, por força elétrica, íons alumínio ou férrico a partir dos eletrodos do sistema. Os íons produzidos são captados pelo ânodo, havendo produção de gás hidrogênio $\left(\mathrm{H}_{2}\right)$ pelo cátodo. Esse gás auxilia no processo de flotação do floculado produzido a partir da reação de formação dos íons metálicos do sistema (ânodo) com o cromo, com posterior remoção (CHEN, 2004). A proposta, nesse caso, é a redução do cromo $\mathrm{VI}$ a cromo III, no cátodo, antes da reação de precipitação do metal na forma de hidróxido (HEIDMANN; CALMANO, 2008).

Nanotubos de carbono - técnica descrita com grande potencial de remoção de metais pesados presentes no efluente, que consiste na passagem da solução contaminada por microtubos em disposição helicoidal, elaborados com carbono grafite (IIJIMA, 1991). Seu funcionamento parece estar voltado aos mecanismos de atração eletrostática, sorção e precipitação e interação química entre os íons metálicos presentes na solução, que entram em contato com a estrutura tubular, e a nanoscópica superfície do material (RAO et al., 2007). A capacidade de sorção desses materiais é radicalmente aumentada após tratamento oxidativo dos nanotubos com soluções de ácido nítrico $\left(\mathrm{HNO}_{3}\right)$, hipoclorito de sódio ( $\mathrm{NaClO}$ ) e permanganato de potássio $\left(\mathrm{KMnO}_{4}\right)$ (FU; WANG, 2011).

Eletrodiálise - procedimento mediado por passagem da solução contaminada por membrana polarizada (membrana de troca iônica), que induz a passagem de íons entre diferentes sistemas de soluções aquosas, através de campo elétrico. Amplamente utilizado para a remoção de sais, em processo de dessalinização, de resíduos de metais pesados de efluentes e outros líquidos (SADRZADEHA et al., 2009), bem como de cromo III e cromo VI (LAMBERT et al., 2006; NATARAJ et al., 2007).
Flotação de íons - essa técnica visa à aglutinação, em micelas, de íons metálicos presentes em efluentes hidrofóbicos, com o auxílio de surfactantes e posterior remoção com auxílio de ar insuflado no sistema (POLAT; ERDOGAN, 2007). Os autores utilizaram duodecil sulfato de sódio (SDS) e hexadeciltrimetil brometo de amônio como agentes surfactantes, e etanol e metil-isobutilcarbinol como agente de flotação, alcançando eficiência de $80 \%$ na remoção de cromo III, em condições controladas, em faixa de $\mathrm{pH}$ alcalino.

Ultrafiltração - técnica mediada por baixa pressão transmembrana para a remoção de metais pesados em soluções e coloides. Para que íons metálicos, na forma de hidretos e complexos de baixo peso molecular, passem facilmente pelos poros da membrana filtrante, algumas adaptações se fazem necessárias. 0 emprego de polímeros solúveis em água promove sua complexação com metais pesados, formando moléculas de peso molecular maior que o limite de tamanho dos poros da membrana, promovendo a retenção do complexo polímero-metal, oferecendo, ainda, a vantagem de recuperação dos resíduos metálicos e reutilização do polímero (FU; WANG, 2011). A eficiência de remoção de cromo varia com o tipo de polímero utilizado, tipo de membrana filtrante empregada, faixa de $\mathrm{pH}$ da solução, a razão de concentração do metal e do polímero, além da presença de outros elementos que podem estar presentes no efluente e que, porventura, possam influenciar no processo. A membrana de polietersulfona, juntamente empregada com polímero de carboximetilcelulose, utilizados em tratamento de efluente com $\mathrm{pH} 7$, alcançou eficiência de $99 \%$ na remoção de cromo III (BARAKAT;SCHMIDT, 2010), enquanto a membrana AMICON 8400, juntamente com polietileneimina e poliacrilato de sódio, em $\mathrm{pH}$ na faixa de 6, mostrou eficiência de 82 a $100 \%$ na remoção de cromo III e cromo VI (KORUS; LOSKA, 2009).

Nanofiltração - técnica que também envolve permeabilidade de membrana, mas com propriedade inferior à técnica de ultrafiltração. Apresenta a vantagem de facilidade de operação, consumo reduzido de energia, 
aplicabilidade e alta eficiência de remoção de metais (ERIKSON, 1988), além de viável alternativa para a remoção de cromo $\mathrm{VI}$ no tratamento de efluente contaminado, no que tange à economia de gastos e, portanto, menos onerosa (MUTHUKRISHNAN; GUHA, 2008).

Metodologias que utilizam materiais adsorventes e membranas filtrantes são as principais alternativas para remover metais pesados de efluentes contaminados, embora tenha de se considerar que sistemas os quais utilizam fotocatálise, que consomem fótons na faixa de luz ultravioleta (UV), sejam mais promissores em um futuro. Em termos de custo e economia, a técnica de precipitação é uma das mais eficientes para a remoção de metais pesados e que está presente em altas concentrações, como é o caso de águas de atividades de mineração e efluentes industriais de curtume. A melhor alternativa deve envolver a aplicabilidade da metodologia, bem como o baixo custo e eficiência do processo (BARAKAT, 2011).

Substâncias quelantes também são amplamente utilizadas para a remoção de metais pesados no tratamento de efluente industrial e lodo. $O$ ácido etilenodiaminotetracético (EDTA) apresenta ótima capacidade quelante para metais pesados catiônicos, e é empregado na recuperação de diferentes tipos de solos e remediação in situ. A principal característica desse composto orgânico é a formação de complexos metálicos altamente estáveis (SUN et al., 2001; LIM et al., 2005). Outras duas substâncias que são empregadas na quelação de cromo são o ácido acético $\left(\mathrm{C}_{2} \mathrm{H}_{4} \mathrm{O}_{2}\right)$ e ácido clorídrico $(\mathrm{HCl})$. Esses três produtos foram comparados na remoção de cromo em lodo oriundo de refinaria de óleo (GITIPOUR et al., 2016), e os ensaios indicaram alta eficiência no uso de $0,3 \mathrm{MHCl}$, com mais de $82 \%$ de remoção do cromo, seguindo com eficiência superior a $72 \%$ no uso de $0,1 \mathrm{M}$ EDTA e, por fim, $47 \%$ de eficiência na remoção de cromo utilizando $3 \mathrm{M}$ $\mathrm{C}_{2} \mathrm{H}_{4} \mathrm{O}_{2}$, apontando para um sucesso de remoção de cromo por ácido clorídrico.

A recuperação de cromo a partir dos resíduos sólidos de curtume mostra um bom desempenho através do emprego de agentes oxidantes. Erdem (2006) recuperou o cromo contido em aparas curtidas através de incineração do resíduo à temperatura de $850^{\circ} \mathrm{C}$, removendo toda a fração orgânica presente no resíduo, e utilizando, posteriormente, uma solução de peróxido de sódio $\left(\mathrm{NA}_{2} \mathrm{O}_{2}\right)$ como agente oxidante. Obteve êxito ao recuperar cerca de $99 \%$ do cromo contido na parte inorgânica do resíduo. Macchi et al. (1991) avaliaram a separação de cromo III através da oxidação a cromo $\mathrm{VI}$, utilizando ácido sulfúrico $\left(\mathrm{H}_{2} \mathrm{SO}_{4}\right)$ como agente oxidante, objetivando recuperar o cromo hexavalente. Ainda, Souza e Silva et al. (2006) extraíram $92 \%$ de cromo contido em lodos de galvanoplastia utilizando peróxido de hidrogênio $\left(\mathrm{H}_{2} \mathrm{O}_{2}\right)$ à temperatura de $60^{\circ} \mathrm{C}$, confirmando a performance desse produto como agente oxidante. Os resultados mostram que técnicas que utilizam soluções com agentes oxidantes para mediar a remoção do cromo para posterior reutilização do metal são avaliadas com bom rendimento. Contudo, o auxílio da técnica através o uso de altas temperaturas pode encarecer 0 processo $\mathrm{e}$ tornar o tratamento oneroso.

O potencial biotecnológico do emprego de biomassa na remoção de metais pesados tem sido amplamente explorado nas duas últimas décadas, principalmente em virtude do seu baixo custo, comparado a tratamentos químicos (Quadro 2). A biossorção, que trata da retenção de metais pesados e outros elementos tóxicos por meio de constituintes celulares de plantas, algas e micro-organismos vivos ou mortos, e a biotransformação, que é a conversão química de compostos mediada por enzimas e metabólitos, e que geram produtos diferentes do original (formas menos tóxicas), são duas das estratégias biológicas mais utilizadas para remediação de ambientes contaminados (IYER et al., 2004).

Os exopolissacarídeos (EPS) são carboidratos produzidos majoritariamente por bactérias e plantas, e são produzidos pela célula e excretados. Podem integrar a parede celular, ou formar umbiopolímero extracelular, com diversas funções fisiológicas envolvidas na proteção contra desidratação e sobrevivência, bem como estocagem de nutrientes. Os EPS de células bacterianas são comumente empregados na remediação de metais pesados de efluentes cloacais e industriais (LAKZIAN, 2008). Uma gama de monômeros, como 
glicose, frutose, ácido glicurônico e $\mathrm{N}$ acetilglicosamina, podem constituir a secreção de EPS por diversos grupos bacterianos e, biotecnologicamente, serem aplicados de forma biossortiva, seja por meio da exploração de células vivas ou mortas, em consórcios de diferentes gêneros (KILIÇ et al., 2015), de forma imobilizada e, também, modificada quimicamente. A sorção ocorre pela interação entre a carga positiva dos íons metálicos e a carga negativa do biopolímero (GUPTA; DIWAN, 2017). EPS de células bacterianas são capazes de sorver a forma mais tóxica de cromo VI (IYER et al., 2004; SULTAN et al., 2012), e linhagens de cianobactérias dos gêneros Nostoc sp. e Gloeocapsa sp. já foram relatadas para sequestro de cromo em ambiente aquático contaminado (SHARMA et al., 2008).

Quadro 2: Técnicas com atividades biológicas na remoção de cromo III e VI de efluentes, resíduos e ambientes contaminados

\begin{tabular}{|c|c|c|}
\hline Técnica & Fundamento & Referência \\
\hline Biossorção & $\begin{array}{l}\text { Adsorção de metais pesados em } \\
\text { exopolissacarídeos produzidos por organismos. } \\
\text { Atração de cargas positivas (metais) e negativas } \\
\text { (EPS) }\end{array}$ & Gupta; Diwan, 2017 \\
\hline Biotransformação & $\begin{array}{l}\text { Transformação metabólica de compostos tóxicos } \\
\text { a formas menos ou não tóxicas }\end{array}$ & lyer et al., 2004 \\
\hline Biorremediação & $\begin{array}{l}\text { Emprego de micro-organismos adaptados a altas } \\
\text { concentrações e metais pesados }\end{array}$ & Bento et al., 2005 \\
\hline Biossurfactantes & $\begin{array}{l}\text { Emprego de moléculas anfipáticas, com formação } \\
\text { e micelas e efeito emulsificante }\end{array}$ & Gnanamani et al., 2010 \\
\hline Fitorremediação & $\begin{array}{l}\text { Acúmulo de metais pesados em tecidos de } \\
\text { plantas e algas }\end{array}$ & Saha et al., 2017 \\
\hline Probióticos & $\begin{array}{l}\text { Terapia com uso de bactérias com efeitos } \\
\text { benéficos e detoxicantes }\end{array}$ & Monachese et al., 2012 \\
\hline
\end{tabular}

Fonte: Dos autores.

Em razão de sua alta taxa de divisão celular e versatilidade metabólica, as bactérias são alvo de investigação e exploração das habilidades de biorremediação de ambientes contaminados com metais pesados. Linhagens de bactérias isoladas, bem como comunidades de bactérias indígenas de ambientes e efluentes contaminados, e que são conhecidas por seus mecanismos de sobrevivência, resistência e adaptação a altas concentrações de cromo, podem auxiliar no processo de remoção ou redução do cromo VI a cromo III (HECK et al., 2015; CARLOS et al., 2016). A técnica de bioaumentação, ou seja, a adição de nutrientes como carbono, nitrogênio e fósforo ao ambiente contaminado onde bactérias resistentes se desenvolvem ou onde receberá os isolados resistentes, favorece seu crescimento e acelera o processo de biorremediação, otimizando a redução do cromo (CARLOS et al., 2016). O emprego da bioaumentação em ambientes contaminados pode fornecer ótimos resultados ao se inocular linhagens bacterianas conhecidas e selecionadas pelo seu desempenho na remoção do metal pesado, fazendo aumentar as populações especializadas e a diversidade no local (BENTO et al., 2005).

Biossurfactantes são moléculas anfifílicas produzidas por bactérias. Suas duas porções hidrofílica e hidrofóbica aumentam a área de contato de substâncias hidrofóbicas em solução aquosa e reduzem a tensão superficial, aumentando a biodisponibilidade através da emulsão por formação de micelas (DESAl; BANAT, 1997). Biossurfactantes apresentam a 
propriedade de mobilização e remoção de metais pesados em solos contaminados (JUWARKAR et al., 2008), cuja confirmação foi alcançada pela identificação da atividade de diramnolipídeo produzido por uma linhagem estudada de Pseudomonas aeruginosa, inclusive, diagnosticando a eficiência na remoção de cromo. O cromo VI também foi biorremediado por uma linhagem de bactéria de ambiente marinho (Bacillus sp. 5514), por meio de redução a cromo $\mathrm{III}$, por ação da enzima cromato redutase, e posterior sequestro do cromo trivalente por ação de biossurfactante (GNANAMANI et al., 2010).

Plantas e algas também são utilizadas como ferramentas de fitorremediação. Trata-se do acúmulo de metais pesados nos tecidos do organismo, seja por mecanismo de pressão osmótica durante a absorção de água pelas raízes, ou por proteção e defesa, o que garante sobrevivência em ambientes inóspitos. Há registro de análises de tecidos de plantas acumuladoras encontradas em regiões de mineração inativas, nas quais foram encontradas altas concentrações de cromo nas raízes, entre outros metais que estavam acima dos limites recomendados pela Organização Mundial da Saúde (BOECHAT et al., 2016). A contrapartida da fitorremediação é o risco para a saúde humana, ao se consumir uma planta bioacumuladora, bem como o destino de disposição do vegetal após sua remoção do local contaminado (KILIÇ; FONT et al., 2011). Efluentes oriundos de mina extrativista contaminados com cromo VI foram fitorremediados com Eichhornia crassipes, uma planta aquática que removeu $99,5 \%$ do resíduo de cromo em curto tempo (15 dias) (SAHA et al., 2017). As algas também são abundantes em águas litorâneas e continentais, e apresentam como atrativo sua capacidade de absorver íons metálicos, além de ter baixo custo de manutenção em virtude da propriedade fotossintética (APIRATIKUL; PAVASANT, 2008). Um exemplo é Ulva lactuca e sua capacidade de absorção de cromo presente em efluente (EL-SIKAILY et al., 2007).

Por fim e, ainda, sobre as alternativas em tratamentos biológicos para remoção de cromo ou redução de cromo VI a cromo III, os lactobacilos são bactérias probióticas que apresentam propriedades de redução de estresse oxidativo ocasionado pela toxicidade promovida pela ingestão de metais pesados através de água e alimentos contaminados. A exposição de lactobacilos ao cromo pode gerar, com o passar do tempo, o desenvolvimento de linhagens resistentes ao metal pesado (UPRETI et al., 2011). Assim, essas bactérias são de suma importância na biorremediação de ambientes contaminados e, ao mesmo tempo, como bioindicadores de segurança alimentar, o que reflete, também, na promoção da tolerância a metais pesados no trato digestivo humano (MONACHESE et al., 2012).

O lodo de curtume, embora rico em cromo, apresenta quantidades significativas de matéria orgânica, como carbono, nitrogênio e fósforo, o que favorece os estudos para utilização de lodos de curtume como fertilizantes em solos a partir da recuperação do cromo presente, além da elaboração de materiais inertes (Quadro 3). A fonte de nitrogênio destes resíduos é proveniente dos pelos das peles tratadas, do colágeno e outras proteínas (HAROUN et al., 2007; OLIVEIRA, 2007; CASTRO, 2011; VIANA; CRUZ, 2016).

Estudos têm sido realizados no intuito de avaliar os impactos do reaproveitamento de lodos e sua disposição em culturas diversas. Durante três anos, Gianello et al. (2011) realizaram experimentos com aplicação de resíduos sólidos de curtumes (lodos de estação de tratamento de efluente, aparas curtidas ao cromo e serragem de rebaixadeira) em três tipos de solos direcionados para o cultivo de sorgo (Sorghum graniferum) e rabanete (Raphanus sativus), sendo constatado, durante esse experimento, que a quantidade de cromo não afetou o crescimento das plantas, quando realizada calagem e adubação mineral, e a quantidade de cromo nas partes comestíveis das plantas também não excedeu os teores recomendados para o consumo.

Um outro estudo, realizado em Eldorado do Sul (Rio Grande do Sul, Brasil), levou em consideração um cultivo de soja (Glycine max L. Merrill) e milho e (Za mays $L$ ) utilizando três tipos de resíduos de curtume: a) adição ao solo de lodo de curtume, resíduo carbonífero, fosfato e potássio; b) tratamento com adubação mineral completa $(\mathrm{N} / \mathrm{P} / \mathrm{K})$ e serragem de couro; c) cromo mineral e lodo de curtume com adubação de potássio e fosfato. Os resultados 
mostraram que a adição de lodo de curtume promoveu aumento do $\mathrm{pH}$ do solo, bem como o teor de cálcio trocável no solo. O único metal que apresentou aumento significativo de sua concentração no solo foi o cromo. A adição de lodo de curtume proporcionou resultados semelhantes à adição de fertilizante nitrogenado no milho e na soja. A serragem de couro que foi adicionada não influenciou nas culturas de milho e soja (FERREIRA et al., 2003).

\section{Quadro 3: Métodos de reaproveitamento dos resíduos produzidos em atividade de curtume em} solos e culturas e na fabricação e materiais

\begin{tabular}{|c|c|c|}
\hline Técnica & Fundamento & Referência \\
\hline $\begin{array}{l}\text { Incorporação de resíduo } \\
\text { em culturas e solos }\end{array}$ & $\begin{array}{l}\text { Incorporação de lodo, aparas e serragem } \\
\text { do couro em solo de cultivo de sorgo e } \\
\text { rabanete. Sem efeitos prejudiciais ao } \\
\text { crescimento dos vegetais. Sem riscos de } \\
\text { toxicidade pelos vegetais. } \\
\text { Incorporação de lodo de curtume em solo } \\
\text { e cultivo de soja e milho. Efeito } \\
\text { semelhante à adição de fertilizante } \\
\text { nitrogenado. Sem influência no } \\
\text { crescimento das plantas. } \\
\text { Incorporação de aparas e serragens de } \\
\text { couro curtido; colágeno da pele. Efeito } \\
\text { positivo ao crescimento de capim- } \\
\text { elefante; baixas concentrações de cromo } \\
\text { em folhas e eucalipto. } \\
\text { Compostagem de lodo de curtume. } \\
\text { Sanitização do lodo e biodegradação } \\
\text { aeróbia e estabilização por atividade } \\
\text { microbiana. }\end{array}$ & $\begin{array}{l}\text { Oliveira, 2007; Castro, } \\
2011\end{array}$ \\
\hline $\begin{array}{l}\text { Incorporação do resíduo } \\
\text { na elaboração de materiais }\end{array}$ & $\begin{array}{l}\text { Serragem do couro curtido. Misturado à } \\
\text { borracha natural e fuligem e carvão, é } \\
\text { utilizado para a fabricação de pisos } \\
\text { antiestáticos. } \\
\text { Semicondutores orgânicos } \\
\text { Extração de cromo por tratamento. } \\
\text { Produção de pigmentos em cerâmicas. } \\
\text { Lodo de curtume. Emprego na construção } \\
\text { civil - incorporação em tijolos e cerâmica, } \\
\text { em baixos percentuais de mistura. } \\
\text { Serragem de resíduo do couro. Emprego } \\
\text { na construção civil - mistura na produção } \\
\text { de argamassa. } \\
\text { Resíduos do couro. Emprego na } \\
\text { construção de móveis - estofamento e } \\
\text { automóveis, móveis, isolamento térmico e } \\
\text { acústico. }\end{array}$ & $\begin{array}{l}\text { Nashy et al., } 2012 \\
\text { Abreu; Toffoli, } 2009 \\
\text { Basegio et al., } 2001\end{array}$ \\
\hline
\end{tabular}

Fonte: Dos autores. 
Numa segunda avaliação sobre os efeitos da incorporação de resíduos sólidos gerados por curtumes em culturas, as aparas e serragens de couros curtidos e tratados para a retirada de cromo e, posteriormente, o colágeno contido nas peles foram utilizados em dois processos: como adsorvente de contaminantes orgânicos e como fonte de nitrogênio para plantas. Esse reaproveitamento mostrou resultados positivos para o cultivo de capim-elefante (OLIVEIRA, 2007). Outro estudo de aproveitamento de resíduos de couro contendo cromo mostrou resultado produtivo à silvicultura. Após a extração do cromo do resíduo, este foi utilizado em cultivos de eucalipto para que o colágeno, ainda presente no resíduo, liberasse nitrogênio para a planta. O resultado foi satisfatório em termos de quantidade de nitrogênio disponibilizado, bem como a baixa concentração de cromo apresentada nas partes aéreas (folhas) do eucalipto desenvolvido (CASTRO, 2011).

A compostagem tem sido um método econômica e ambientalmente viável para estabilizar o resíduo de lodo de estação de tratamento de efluentes de curtume para a fertilização dos solos (FERREIRA et al., 2003; ZHOU et al., 2006; AMIR et al., 2008; HAROUN et al., 2009; GIANELLO et al., 2011; HECK et al., 2013). A técnica consiste na degradação de fontes de moléculas orgânicas para obtenção de energia, com consumo de oxigênio, sendo realizado especialmente por micro-organismos, como bactérias, actinobactérias e fungos (PALMISANO; BARLAZ, 1996). Os resíduos são dispostos em pilhas compactadas, com monitoramento periódico, incluindo aeração e controle da umidade. No entanto, como os micro-organismos não são capazes de metabolizar os metais pesados, estes tendem ao acúmulo à medida que o processo avança em direção à maturação do composto, podendo selecionar bactérias resistentes a metais pesados, as quais seriam posteriormente lançadas ao solo (HECK et al., 2015). Além disso, materiais tratados e utilizados como fertilizantes, que contêm altas concentrações de metais pesados, podem ser nocivos à microbiota do solo que irá receber o insumo (VELA-CANO et al., 2014). Tendo em vista esse viés da compostagem do lodo de curtume, é sugerido que as concentrações de cromo presentes no material sejam reduzidas e monitoradas (BRASIL, 2006).

Resíduos sólidos, como a serragem do couro curtido, foram incorporados para a fabricação de pisos antiestáticos com sucesso, e mostraram viabilidade para serem utilizados como material de enchimento inerte na produção de compostos políméricos que possuem a borracha natural da seringueira como matriz. Mais especificamente, a invenção utiliza os resíduos provenientes do couro (serragem de rebaixadeira) como base para o compósito com propriedades antiestáticas. $O$ resíduo de couro, misturado com borracha natural e negro de fumo (fuligem de carvão), promove a obtenção de um material que pode ser utilizado no revestimento de superfícies e que anula a carga estática. Oferece utilidade na composição de pisos e revestimentos na construção civil, projetos especiais de engenharia, indústrias produtoras de gases e/ou solventes explosivos e inflamáveis, indústrias de circuitos eletrônicos, placas eletrônicas e outros (RUIZ et al., 2015).

O aproveitamento de resíduos sólidos de curtume pode ocorrer, também, no processo de fabricação de semicondutores orgânicos (NASHY et al., 2012). A extração de cromo de lodo de curtume para aproveitamento em pigmentos para azulejos de cerâmica e vidros é também vista como uma alternativa viável (ABREU; TOFFOLI, 2009). Outras vias seriam a imobilização do cromo em materiais adsorventes, o que já foi testado com casca de camarão (FABBRICINO et al., 2013), e, também, na decomposição térmica do lodo por pirólise (MURALIDHARA et al., 1982; CABALLERO et al., 1998). O lodo também é apresentado como proposta para geração de energia (SKRYPSKI-MÄNTELE; BRIDLE, 1995), e a possibilidade de sua aplicação na construção civil, através da incorporação do resíduo em tijolos de cerâmica vermelha, foi avaliada por meio de testes mecânicos, de lixiviação e solubilização, bem como por análise das emissões gasosas desses tijolos. Os testes foram satisfatórios para incorporação de $10 \%$ de lodo de curtume misturado a outros materiais (BASEGIO et.al., 2001). Resíduos de couro podem também ser utilizados como compósitos expandidos na constituição de almofadas para automóveis e móveis, na 
construção civil para vedar estruturas, bem como para isolamento térmico $\mathrm{e}$ isolamento acústico no fechamento de paredes (CALLISTER, 2015).

A serragem de rebaixadeira, que vem a ser o resíduo do couro, foi testada para sua mistura à argamassa de cimento, após a inertização do cromo III presente no resíduo. A inertização do cromo impediu a capacidade de lixiviação do metal pesado e garantiu a resistência mecânica da mistura através de teste de compressão (TACHARD, 2006). Em outro estudo, o cromo foi removido de resíduos de curtume para possibilitar sua utilização, já que o material é rico em colágeno e outros nutrientes, na alimentação de ruminantes. Entretanto, a quantidade de cromo a ser retirada de tal resíduo deve ser da ordem mínima de $99 \%$ de eficiência, para que este metal não acarrete em danos à nutrição animal (SILVA, 2007).

Tendo em vista a crescente geração de resíduos provenientes de lodo de curtumes, no âmbito mundial, sua gestão e métodos novos de tratamento e reutilização se tornam essenciais. Segundo Fathima et al. (2012), existem várias formas de tratamentos e de disposição final de resíduos sólidos, como reutilização, tratamento, armazenamento e disposição final. Assim, diversos subprodutos de atividades industriais, que seriam tradicionalmente tratados como resíduos, têm sido agora vistos como novas fontes de matéria-prima, como os nutrientes (principalmente o nitrogênio) presentes nos resíduos industriais de curtumes.

\section{CONCLUSÃO}

A atividade industrial de curtumes gera grandes quantidades de resíduos sólidos perigosos, principalmente devido aos riscos ocasionados pelo uso do cromo como principal agente curtente. É possível e necessária a adoção de tratamentos que contemplem o reaproveitamento, em detrimento do aterramento de resíduos sólidos de curtumes. Técnicas que empregam métodos físicos e químicos para a remoção de cromo trivalente, bem como a redução de cromo hexavalente e posterior remoção, seguida por técnicas de incorporação e reaproveitamento do lodo oriundo do tratamento do efluente amenizam a sobrevida dos aterros receptores, ao mesmo tempo em que previne a contaminação de solos e mananciais. A precipitação de íons cromo, fazendo uso de agentes quelantes ou precipitantes, bem como o emprego de agentes oxidantes são adequados para remoção do metal presente em elevadas concentrações em solução no efluente. Incorporação do lodo na fabricação de materiais de alvenaria é uma alternativa econômica e rentável, no entanto, futuras investigações são necessárias para inferência sobre a inércia da matéria orgânica e do cromo. Após redução das concentrações ou remoção de cromo, o lodo pode ser aplicado em solos para 0 aproveitamento das propriedades da matéria orgânica, e o monitoramento da área deve ser constante.

\section{REFERÊNCIAS}

ABREU, M.A.; TOFFOLI, S.M. Characterization of a chromium-rich tannery waste and its potential use in ceramics. Ceramics International, v. 35, n. 6, p. 2225-2234, 2009.

ALVES, V.C.; BARBOSA A.S. Práticas de gestão ambiental das indústrias coureiras de Franca-SP. Gestão \& Produção, v. 20, n. 4, p. 883-898, 2013.

AMIR, S.; BENLBOUKHT, F.; CANCIAN, N.; WINTERTON, P.; HAFIDI, M. Physico-chemical analysis of tannery solid waste and structural characterization of its isolated humic acids after composting. Journal of Hazardous Materials, v. 160, n. 2-3, p. 448-455, 2008.

APIRATIKUL, R.; PAVASANT, P. Batch and column studies of biosorption of heavy metals by Caulerpa lentillifera. Bioresource Technology, v. 99, p. 2766-2777, 2008.

BARAKAT, M.A.; SCHMIDT, E. Polymerenhanced ultrafiltration process for heavy metals removal from industrial wastewater. Desalination, v. 256, p. 90-93, 2010.

New trends in removing heavy metals from industrial wastewater. Arabian Journal of Chemistry, v. 4, p. 361-377, 2011.

BASEGIO, T.M.; BERUTTI, F.A.; BERGMANN, C.P. Aspectos ambientais no uso de lodo de 
curtume como matéria-prima para cerâmica vermelha. In: CONGRESSO BRASILEIRO DE CERÂMICA, 45., 2001, Florianópolis. Anais... Florianópolis: Associação Brasileira de Cerâmica, 2001.

BAUTISTA, M.E.; PÉREZ, L.; GARCÍA, M.T.; CUADROS, S.; MARSAL, A. Valorization of tannery wastes: Lipoamino acid surfactant mixtures from the protein fraction of process wastewater. Chemical Engineering Journal, v. 262, p. 399-408, 2015.

BENTO, F.M.; CARMARGO, F.A.O.; OKEKE, B.C.; FRANKENBERGER, W.T. Comparative bioremediation of soils contaminated with diesel oil by natural attenuation, biostimulation and bioaugmentation. Bioresource Technology, v. 9, n. 96, p. 1049-1055, 2005.

BOECHAT, C.L.; CARLOS, F.S.; GIANELLO, C.; CAMARGO, F.A.O. Heavy metals and nutrients uptake by medicinal plants cultivated on multi-metal contaminated soil samples from an abandoned gold ore processing site. Water Air and Soil Pollution, v, 227, p. 392, 2016.

BRASIL. CONAMA - Conselho Nacional do Meio Ambiente. Resolução CONAMA № 375/2006 de 29 de Agosto de 2006. Define critérios e procedimentos, para o uso agrícola de lodos de esgoto gerados em estações de tratamento de esgoto sanitário e seus produtos derivados, e dá outras providências. DOU $\mathrm{n}^{0}$ 167, de 30/08/2006, pág. 141-146. Brasília, DF, 2006 Disponível em: <http://ww///w.mma.gov.br/port/conama/legiano/ > Acesso em: 15 jan. 2017.

Presidência da República Casa Civil Subchefia para Assuntos Jurídicos Lei no 12.395 de 2 de Agosto de 2010. Institui a Política Nacional de Resíduos Sólidos; altera a Lei 9.605 de 12 de fevereiro de 1998; e dá outras providências. Diário Oficial da República Federativa do Brasil, Brasília, DF, 2 ago. 2010. Disponível em: <www.planalto.gov.br/ccivil_03/_ato20072010/.../lei//12305.htm> Acesso em: 15 jan. 2017.

BRUINS, M.R.; KAPIL, S.; OEHME, F.W. Microbial resistance to metals in the environment.

Environmental Safety, v. 45, p. 198-207, 2000.

CABALLERO, J.A.; FONT, R.; ESPERANZA, M.M. Kinetics of the thermal decomposition of tannery waste. Journal of Analytical and Applied Pyrolysis, v. 47, n. 2, p. 165$181,1998$.

CALLISTER, J.W.D. Ciência e engenharia de materiais. Uma introdução. 8. ed. Rio de Janeiro: LTC, 2015.

CARLOS, F.S.; GIOVANELLA, P.; BAVARESCO, J.; BORGES, C.S.; CAMARGO, F.A.O. A comparison of microbial bioaugmentation and biostimulation for hexavalent chromium removal from wastewater. Water Air and Soil Pollution, v. 227, p. 175, 2016.

CASTRO, I.A. Resíduo de couro "wet blue" após a extração do cromo: uso como fertilizante nitrogenado em plantação de eucalipto. 2011. 93 p. Dissertação (Mestrado em Agroquímica) - Universidade Federal de Lavras, Lavras, MG, 2011.

CELARY, P.; SOBIK-SZOKTYSEK, J. Vitrification as an alternative to landfilling of tannery sewage sludge. Waste Management, v. 34, n. 12, p. 2520-2527, 2014.

CETESB. Companhia Ambiental do Estado de São Paulo. Guia Técnico Ambiental de Curtumes. 2. ed. São Paulo, 2015.

CHEN, G.H. Electrochemical technologies in wastewater treatment. Separation and Purification Technology, v. 38, n. 1, p. 11-41, 2004

CHUAN, M.C.; LIU, J. . Release behavior of chromium from tannery sludge. Water Research, v. 30, n. 4, p. 932-938,1996.

DEPARTAMENTO DE PESQUISAS E ESTUDOS ECONÔMICOS - Bradesco (2013). Carne bovina. Disponível em: <http:// www.economiaemdia.com.br/static_files/Econo miaEmDia/Arquivos/infset_carne_bovina.pdf>. Acesso em: 06 jan. 2017). 
DESAI, J.D.; BANAT, I.M. Microbial production of surfactants and their commercial potential. Microbiology and Molecular Biology Research, v. 61, n. 1, p. 47-64, 1997.

EL-SIKAILY, A.; NEMR, A.E.; KHALED, A.; ABDELWEHAB, O. Removal of toxic chromium from wastewater using green alga Ulva lactuca and its activated carbon. Journal of Hazardous Materials, v. 148, p. 216-228, 2007.

ERDEM, M. Chromium recovery from chrome shaving generated in tanning process, Journal of Hazardous Materials, v. 129, n. 1-3, p. 143$146,2006$.

ERIKSON, P. Nanofiltration extends the range of membrane filtration. Environmental Progress and Sustainable Energy, v. 7, p. 58$61,1988$.

FABBRICINO, M.; NAVIGLIO, B.; TORTORA, G.; d'ANTONIO, L. An environmental friendly cycle for $\mathrm{Cr}(\mathrm{III})$ removal and recovery from tannery wastewater. Journal of Environmental Management, v. 117, p. 1-6, 2013.

FATHIMA, N.; RAO, J.R.; NAIR, B.U. Tannery solid waste to treat toxic liquid wastes: a new holistic paradigm. Environmental Engineering Science, v. 29, n. 6, p. 363-372, 2012.

FELA, K.; CIUROWA, K.W.; KONOPKA, M.; WOŹNY, Z. Present and prospective leather industry waste disposal. Polish Journal of Chemical Technology, v. 13, n. 3, p. 53-55, 2011.

FERNÁNDEZ-SEMPERE, J.; BARRUESOMARTÍNEZ, M.L.; FONT-MONTESINOS, R.; SABATER-LILLO, M.C. Characterization of tannery wastes comparison of three leachability tests. Journal of Hazardous Materials, v. 54, n. 1-2, p. 31-45, 1997.

FERREIRA, A.D.S.; CAMARGO, F.A.O.; TEDESCO, M.J.; BIASSINI, C.A. Alterações de atributos químicos e biológicos de solo e rendimento de milho e soja pela utilização de resíduos de curtume e carbonífero. Revista Brasileira de Ciência do Solo, v. 27, n. 4, p. 755-763, 2003.
FREITAS, T.C.M.; MELNIKOV, P. O uso e os impactos da reciclagem de cromo em indústrias de curtume em Mato Grosso do Sul, Brasil. Engenharia Sanitária e Ambiental, v. 11, n. 4, p. 305-310, 2006

FU, F.; WANG, Q. Removal of heavy metal ions from wastewaters: a review. Journal of Environmental Management, v. 92, p. 407418, 2011.

GIANELLO, C.; DOMASZAK, S.C.; BORTOLON, L.; KRAY, C.H.; MARTINS, V. Viabilidade do uso de resíduos da agroindústria coureiro-calçadista no solo. Ciência Rural, v. 41, n. 2, p. 242-245, 2011.

GITIPOUR, S.; AHMADI, S.; MADADIAN, E.; ARDESTANI, M. Soil washing of chromium and cadmium contaminated sludge using acids and ethylenediaminetetra acetic acid chelating agent. Environmental Technology, v. 37, n. 1, p. $145-151,2016$

GNANAMANI, A.; KAVITHA, V.; RADHAKRISHNAN, N.; RAJAKUMAR, G.S.; SEKARAN, G.; MANDAL, A.B. Microbial products (biosurfactant and extracellular chromate reductase) of marine microorganism are the potential agents reduce the oxidative stress induced by toxic heavy metals. Colloids and Surfaces. B, Biointerfaces, v. 79, n. 2, p. 334-339, 2010.

GUPTA, P; DIWAN, B. Bacterial Exopolysaccharide mediated heavy metal removal: a review on biosynthesis, mechanism and remediation strategies. Biotechnology Reports, v. 13p. 58-71, 2017.

HAROUN, M.; IDRIS, A.; OMAR, S. R. S. A study of heavy metals and their fate in the composting of tannery sludge. Waste Management, v. 27, n. 11, p. 1541-1550, 2007.

Analysis of heavy metals during composting of the tannery sludge using physicochemical and spectroscopic techniques. Journal of Hazardous Materials, v. 165, n. $1-3$, p. 111-119, 2009.

HECK K.; DE MARCO, E.G.; HAHN, A.B.B.; KLUGE, M.; SPILKI, F.R.; VAN DER SAND, S.T. Avaliação da temperatura de degradação em processo de compostagem e a qualidade 
microbiológica do composto final. Revista Brasileira de Engenharia Agrícola e Ambiental, v. 17, p. 54-59, 2013.

; DUARTE, M.W.; SALAMONI,

S.P.; VAN DER SAND, S.T. Pattern of multiresistant to antimicrobials and heavy metal tolerance in bacteria isolated from sewage sludge samples from a composting process at a recycling plant in southern Brazil. Environmental Monitoring and Assessment, v. 187, n. 328, p. 1-11, 2015.

HEIDMANN, I., CALMANO, W. Removal of $\mathrm{Zn}(\mathrm{II}), \mathrm{Cu}(\mathrm{II}), \mathrm{Ni}(\mathrm{II}), \mathrm{Ag}(\mathrm{I})$ and $\mathrm{Cr}(\mathrm{VI})$ present in aqueous solutions by aluminium electrocoagulation. Journal of Hazardous Materials, v. 152, p.934-941, 2008.

IIJIMA, S. Helical microtubules of graphitic carbon. Nature, v. 354, p. 56-58, 1991.

IYER, A.; MODY, K.; JHA, B. Accumulation of hexavalent chromium by an exopolysaccharide producing marine Enterobacter cloaceae. Marine Pollution Bulletin, v. 49, n. 11-12, p. 974-977, 2004.

JAISHANKAR, M.; TSETEN, T.; ANBALAGAN, N.; MATHEW, B.B.; BEEREGOWDA, K.N. Toxicity: mechanism and health effects of some heavy metals. Interdisciplinary Toxicology, $v$. 7, n. 2, p. 60-72, 2014.

JUWARKAR, A.A.; DUBEY, K.V.; NAIR, A.; SINGH, S.K. Bioremediation of multi-metal contaminated soil using biosurfactant - a novel approach. Indian Journal of Microbiology, v. 48, p. 142-146, 2008.

KILIÇ, E.; FONT, J.; PUIG, R.; ÇOLAK, S.; ÇELIK, D. Chromium recovery from tannery sludge with saponin and oxidative remediation. Journal of Hazardous Materials, v. 185, n. 1, p. 456-462, 2011.

; PUIG, R.; BAQUERO, G.; FONT, J.; ÇOLAK, S.; GÜRLER, D. Environmental optimization of chromium recovery from tannery sludge using a life cycle assessment approach. Journal of Hazardous Materials, v. 192, n. 1, p. 393-401, 2011.
KILIÇ, N.; KÜRKÇÜ, G.; KUMRUOGLU, D.; DÖNMEZ, G. EPS production and bioremoval of heavy metals by mixed and pure bacterial cultures isolated from Ankara Stream. Water Science and Technology, v. 72, n. 9, p. 14881494, 2015.

KORUS, I.; LOSKA, K. Removal of $\mathrm{Cr}(\mathrm{III})$ and $\mathrm{Cr}(\mathrm{VI})$ ions from aqueous solutions by means of polyelectrolyte-enhanced ultrafiltration.

Desalinationv, n. 247, p. 390-395, 2009.

LAKZIAN, A. Adsorption capability of lead: nickel and zinc by Exopolysaccharide and dried cell of Ensifer meliloti. Asian Journal of Chemistry, v. 20, p.6075-6080, 2008.

LAMBERT, J.; AVILA-RODRIGUEZ, M.; DURAND, G.; RAKIB, M. Separation of sodium ions from trivalent chromium by electrodialysis using monovalent cation selective membranes. Journal of Membrane Science, v. 280, n. 1-2, p. 219-225, 2006.

LIM, T.T.; CHUI, P.C.; GOH, K.H. Process evaluation for optimization of EDTA use and recovery for heavy metal removal from a contaminated soil. Chemosphere, v. 58, p. 1031-1040, 2005.

LOPES, G.S.M. Influência do pré-curtimento da pele para curtimento vegetal. 2016. 57 p. TCC (Graduação em Engenharia Química) Universidade Federal do Rio Grande do Sul, Porto Alegre, RS, 2016.

MACCHI, G.; PAGANO, M.; PETTINE, M.; SANTORI, M.; TIRAVANTI, G. A bench study on chromium recovery from tannery sludge. Water Research, v. 25, n. 8, p. 1019-1026, 1991.

MAKDISI, R.S. Tannery wastes definition, risk assessment and cleanup options, Berkeley, California. Journal of Hazardous Materials, v. 29, n. 1, p. 79-96, 1991.

MIRBAGHERI, S.A.; HOSSEINI, S.N. Pilot plant investigation on petrochemical wastewater treatment for the removal of copper and chromium with the objective of reuse. Desalination, v. 171, p. 85-93, 2005.

MONACHESE, M.; BURTON, J. P.; RELD, G. Bioremediation and tolerance of humans to 
heavy metals through microbial processes: a potential role for probiotics? Applied and Environmental Microbiology, v. 78, n.18, p. 6397-6404, 2012.

MONTAÑÉS, M.T.; SÁNCHEZ-TOVAR, R.; ROUX, M.S. The effectiveness of the stabilization/solidification process on the leachability and toxicity of the tannery sludge chromium. Journal of Environmental Management, v. 143, p. 71-79, 2014.

MURALIDHARA, H.S.; MAGGIN, B.; PHIPPS $J R, H$. Conversion of tannery waste to useful products. Resources and Conservation, v. 8, n. 1, p. 43-59, 1982.

MUTHUKRISHNAN, M.; GUHA, B.K. Effect of $\mathrm{pH}$ on rejection of hexavalent chromium by nanofiltration. Desalination, v. 219, p. 171-178, 2008.

NASHY, E.S.H.A.; AL-ASHKAR, E.; MOEZ, A.A. Optical and spectroscopic studies on tannery wastes as a possible source of organic semiconductors. Spectrochimica Acta Part aMolecular and Biomolecular Spectroscopy, v. 86, p. 33-38, 2012.

NATARAJ, S.K.; HOSAMANI, K.M.; AMINABHAVI, T.M. Potential application of an electrodialysis pilot plant containing ionexchange membranes in chromium removal. Desalination, v, 217, p. 181-190, 2007.

NEPOMUCENO, N.A.S.; SOBRINHO, M.S.; PEREIRA, A.L.F.F.; SALES, J.M.S. Diagnóstico do gerenciamento dos resíduos sólidos nos curtumes do Ceará. In: CONGRESSO BRASILEIRO DE GESTÃO AMBIENTAL, 7., 2016, Campina Grande. Anais... Campina Grande, PB: IBEAS, 2016.

OLIVEIRA, D.Q.L. Tratamento de rejeitos sólidos contendo cromo da indústria de couro: uso em processos de adsorção e como fonte de nitrogênio na agricultura. 2007. 73 p. Dissertação (Mestrado em Agroquímica e Agrobioquímica) - Universidade Federal de Lavras, Lavras, MG, 2007.

PALMISANO, A.C.; BARLAZ, M A. Microbiology of solid waste. Boca Raton: CRC Press, 1996.
POLAT, H., ERDOGAN, D. Heavy metal removal from waste waters by ion flotation. Journal of Hazardous Materials, v. 148, p. 267-273, 2007.

RAO, G.P., LU, C., SU, F. Sorption of divalent metal ions from aqueous solution by carbon nanotubes: a review. Separation and Purificaton Technology, v. 58, p. 224-231, 2007.

RIVELA, B.; MÉNDEZ, R.; BORNHARDT, C.; VIDAL, G. Towards a cleaner production in developing countries: a case study in a Chilean tannery. Waste Management \& Research, v. 22, n. 3, p. 131-141, 2004

RUIZ, M.R.; BUDEMBERG, E.R.; CUNHA, G.P.; BELLUCCI, F.S.; CUNHA, H.N.; JOB, A.E. An innovative material based on natural rubber and leather tannery waste to be applied as antistatic flooring. Journal of Applied Polymer Science, v. 132, n. 3, p. 1-11, 2015.

SADRZADEHA, M.; MOHAMMADI, T.; IVAKPOUR, J.; KASIRI, N. Neural network modeling of $\mathrm{Pb} 2 \mathrm{p}$ removal from wastewater using electrodialysis. Chemical Engineering and Processing, v. 48, n, 8, p. 1371-1381, 2009.

SAHA, P.; SHINDE, O.; SARKAR, S. Phytoremediation of industrial mines wastewater using water hyacinth. International Journal of Phytoremediation, v. 19, n. 1, p. 87-96, 2017.

SANTOS, G.S.; PAETZOLD, L.J.; SEHNEM, S.; DIAS, T. Análise do nível de sustentabilidade de um curtume a partir do estudo do sistema de gestão ambiental - SGA. Sistemas \& Gestão, v. 10, p. 216-339, 2015.

SHARMA, M.; KAUSHIK, A.; BALA, K.; KAMRA, A. Sequestration of chromium by exopolysaccharides of Nostoc and Gloeocapsa from dilute aqueous solutions. Journal of Hazardous Materials, v. 157, p.315-318,2008.

SILVA, R.C. Utilização de rejeito de couro wet blue na alimentação de ruminantes: potencialidades nutricionais e patológicas. 2007. 69p. Dissertação (Mestrado em Ciências 
Veterinárias) - Universidade Federal de Lavras, Lavras, MG, 2007.

SKRYPSKI-MÄNTELE, S.; BRIDLE, T.R. Environmentally sound disposal of tannery sludge. Water Research, v. 29, n. 4, p. 10331039, 1995.

SOUZA E SILVA, P.T.; MELLO, N.T.; DUARTE, M.M.M.; MONTENEGRO, M.C.; ARAÚJO, A.N.; BARROS NETO, B.; SILVA, V.L. Extraction and recovery of chromium from electroplating sludge. Journal of Hazardous Materials, v. 128, n. 1, p. 39-43, 2006.

SULTAN, S.; MUBASHAR, K.; FAISAL, M. Uptake of toxic $\mathrm{Cr}(\mathrm{VI})$ by biomass of exopolysaccharides producing bacterial strains. African Journal of Microbiology Research, v. 6, p.3329-3336, 2012.

SUN, B.; ZHAO, F.J.; LOMBI, E.; MCGRATH, S.P. Leaching of heavy metals from contaminated soils using EDTA. Environmental Pollution, v. 113, p. 111-120, 2001.

TACHARD, A.L.R.S.; RIBEIRO, D.V.; MORELLI, M.R. Avaliação da resistência mecânica de argamassas de cimento Portland contendo serragem de couro tratado em meio ácido. In: CONGRESSO BRASILEIRO DE ENGENHARIA E CIÊNCIA DOS MATERIAIS CBECIMat, 17., 2006, Foz do Iguaçu. Anais... Foz do Iguaçu: Associação Brasileira de Cerâmica, 2006.
PRETI, R.K.; SINHA, V.; MISHRA, R.; KANNAN, A. In vitro development of resistance to arsenite and chromium-VI in lactobacilli strains as perspective attenuation of gastrointestinal disorder. Journal of Environmental Biology, v. 32, n. 3, p. 325332, 2011.

VELA-CANO, M.; CASTELLANO-HINOJOSA, A.; VIVAS, A.F.; TOLEDO, M.V.M. Effect of heavy metals on the growth of bacteria isolated from sewage sludge compost tea. Advances in Microbiology, v. 4, p. 644-655, 2014.

VIANA, L.G.; CRUZ, P.S. Reaproveitamento de resíduos agroindustriais. In: CONGRESSO BAIANO DE ENGENHARIA SANITÁRIA E AMBIENTAL - COBESA, 4., 2016, Cruz das Almas. Anais... Cruz das Almas: Universidade Federal do Recôncavo Baiano, 2016.

YANG, B.S. Industrial processes and waste characterization. Resources, Conservation and Recycling, v. 16, n. 1-4, p. 93-112, 1996.

ZHOU, S.G.; ZHOU, L.X.; WANG, S.M.; FANG, D. Removal of $\mathrm{Cr}$ from tannery sludge by bioleaching method. Journal of Environmental Sciences, v. 18, n. 5, p. 885890, 2006.

ZOU, D.; CHI, Y.; DONG, J.; FU, C.; WANG, F.; $\mathrm{NI}, \mathrm{M}$. Supercritical water oxidation of tannery sludge: stabilization of chromium and destruction of organics. Chemosphere, v. 93, n. 7, p. 1413-1418, 2013. 